\title{
Case Report \\ A Pathogenic Presenilin-1 Val96Phe Mutation from a Malaysian Family
}

\author{
Eva Bagyinszky ${ }^{1}\left(\mathbb{D}\right.$, Gaik-Siew Ch'ng $^{2, *}{ }^{-\infty}$, Mei-Yan Chan $^{3}$, Seong Soo A. An ${ }^{4, *}$ and SangYun Kim ${ }^{5}$ \\ 1 Department of Industrial and Environmental Engineering, Graduate School of Environment, Gachon \\ University, Seongnam 13120, Korea; navigator120@gmail.com \\ 2 Department of Genetics, Penang Hospital, Penang 10990, Malaysia \\ 3 Department of Genetics, Kuala Lumpur Hospital, Kuala Lumpur 50586, Malaysia; meiyanc@yahoo.com \\ 4 Department of Bionano Technology, Gachon University, Seongnam 13120, Korea \\ 5 Department of Neurology, Seoul National University College of Medicine \& Neurocognitive Behavior Center, \\ Seoul National University Bundang Hospital, Seongnam 13620, Korea; neuroksy@snu.ac.kr \\ * Correspondence: gaiksiew@yahoo.com (G.-S.C.); seong.an@gmail.com (S.S.A.A.)
}

Citation: Bagyinszky, E.; Ch'ng, G.-S.; Chan, M.-Y.; An, S.S.A.; Kim, S. A Pathogenic Presenilin-1 Val96Phe Mutation from a Malaysian Family. Brain Sci. 2021, 11, 1328. https:// doi.org/10.3390/brainsci11101328

Academic Editors: Johannes Schröder and Lawrence J. Whalley

Received: 9 September 2021

Accepted: 30 September 2021

Published: 8 October 2021

Publisher's Note: MDPI stays neutral with regard to jurisdictional claims in published maps and institutional affiliations.

Copyright: (c) 2021 by the authors. Licensee MDPI, Basel, Switzerland. This article is an open access article distributed under the terms and conditions of the Creative Commons Attribution (CC BY) license (https:/ / creativecommons.org/licenses/by/ $4.0 /)$.
Abstract: Presenilin-1 (PSEN1) is one of the causative genes for early onset Alzheimer's disease (EOAD). Recently, emerging studies have reported several novel PSEN1 mutations among Asians. In this study, a PSEN1 Va196Phe mutation was discovered in two siblings from Malaysia with a strong family history of disease. This is the second report of PSEN1 Val96Phe mutation among EOAD patients in Asia and in the world. Patients presented symptomatic changes in their behaviors and personality, such as apathy and withdrawal in their 40s. Previous cellular studies with COS1 cell lines revealed the mutation increased the amyloid- $\beta 42$ (A $\beta 42)$ productions. In the present study, wholeexome sequencing was performed on the two siblings with EOAD, and they were analyzed against the virtual panel of 100 genes from various neurodegenerative diseases. In silico modeling was also performed on PSEN1 Val96Phe mutation. This mutation was located on the first transmembrane helix of PSEN1 protein, resulting significant intramolecular stresses in the helices. This helical domain would play a significant role in $\gamma$-secretase cleavage for the increased A $\beta 42$ productions. Several other adjacent mutations were reported in this helical domain, including Ile83Thr or Val89Leu. Our study suggested that perturbations in TMI-HLI-TMII regions could also be associated with C-terminal fragment accumulation of APP and enhanced amyloid productions.

Keywords: Alzheimer's disease; mutation; whole-exome sequencing; presenilin1

\section{Introduction}

Early-onset Alzheimer's disease (EOAD) occurs before than 65 years of age and represents only a minority of all AD cases (less than 5\%). Presenilin1 (PSEN1, NC_000014.9) was verified as one of the major causative factors for EOAD. More than 300 pathogenic mutations were found in PSEN1 (http:/ / www.alzforum.org/mutations/psen-1, accessed on 1 September 2020). Mutations in PSEN1 may represent clinical heterogeneity, since besides cognitive dysfunctions and memory decline, additional disease phenotypes could present, such as spastic paraparesis, language-and behavioral dysfunctions or Parkinsonism [1]. Patients with PSEN1 mutation could usually develop disease in their 40s or 50s. In addition, several cases of young onset AD were also reported with clinical phenotypes of cognitive declines in their 30s or even earlier [2-4].

Presenilin proteins are members of gamma secretase complex, which plays a role in the cleavage of APP protein. PSEN1 participates as a catalytic subunit of intramembranous aspartyl protease, inducing $\gamma$-secretase cleavage at C99 for the production of $\beta$-amyloid peptide $(\mathrm{A} \beta)$. A $\beta$ peptide could exist in various lengths, such as $43,42,40$, or 38 amino acids residues. Pathogenic PSEN1 mutations would modify the $\gamma$-secretase activity, resulting in 
elevated ratio of $A \beta 42 / A \beta 40[3,4]$. Alternatively, PSEN1 mutations could reduce the $\alpha-$ secretase cleavage, resulting in reduced production of $A \beta 40$. In addition, low levels of $A \beta 40$ against $A \beta 42$ may reduce the degree of $A \beta 42$ clearance and enhance the accumulations of $A \beta 42$ [3-5]. Elevated $A \beta 42$ and reduced secretion of $A \beta$ species could increase ratio of A $\beta 42 / \mathrm{A} \beta 40$ [5-7].

Here, we reported a pathogenic mutation, PSEN1 Val96Phe (c.286G >T) in a Malaysian family. PSEN1 Val96Phe mutation was initially described in a Japanese family, with similar age of onset [8]. The Malaysian family was briefly mentioned in our previous publication [9]. In the current study, detailed clinical phenotypic presentation and the structure predictions will also be presented.

\section{Materials and Methods}

Patients provided written informed consent, which allowed the genetic and clinical data to be used for research purposes. A diagnosis of probable AD was carried out, according to the criteria of the National Institute of Neurological and Communicative Disorders and Stroke Alzheimer' Disease and Related Disorders Association [10]. Detailed clinical phenotypes, family history and imaging data are presented in the Results (Section 3.1).

White blood cells (Buffy coat) have been separated from plasma after centrifugation at $800 \mathrm{~g}$ for $30 \mathrm{~min}$. Genomic DNA was extracted using the QIAcube system (Qiagen) and both the quantity and quality of extracted DNA were measured using Nanodrop ND-1000 Spectrometer (NanoDrop, Thermo Fisher Scientific., Seoul, Korea). Whole-exome sequencing (WES) was performed on the two siblings by Novogene Inc (https: / / en.novogene.com, accessed on 1 September 2020; Hong Kong). A total of $2 \mu \mathrm{g}$ of genomic DNA used for genetic analysis. After library preparation sequencing was performed on Illumina platform. Whole annotation of data was received by excel file, and sequencing data were sent as a ".bam" file, which were visualized by Integrative Genomics Viewer (IGV) software. Data were analyzed by a "virtual gene panel" of 100 possible genes from different neurodegenerative diseases, including Alzheimer's disease, Parkinson's disease, frontotemporal dementia, and prion diseases (Supplementary Table S1 and S2).

Probable pathogenic mutations were discovered by WES and verified by standard sequencing [11], performed by BioNeer Inc. (Dajeon, Korea), using Big Dye Terminator Cyclic sequencing, and data were analyzed using an ABI 3730XL DNA Analyzer (Bioneer Inc., Dajeon, Korea). The data were aligned by NCBI Blast (http:/ /blast.ncbi.nlm.nih.gov/ Blast.cgi, accessed on 1 September 2020). Mutations were screened against the reference databases, including Korean Reference Genome Database (KRGDB, http:/ /152.99.75.16 8/KRGDB/menuPages/intro.jsp, accessed on 1 September 2020), GnomAD (https:// gnomad.broadinstitute.org/, accessed on 1 September 2020), and 1000 Genomes (http: //www.1000genomes.org/, accessed on 1 September 2020) databases.

In terms of in silico analyses for the potential pathogenic mutations, each variant was analyzed by PolyPhen-2 (http:/ /genetics.bwh.harvard.edu/pph2/, accessed on 1 September 2020), Sorting Intolerant From Tolerant algorithm (SIFT; http:/ / sift.jcvi.org/, accessed on 1 September 2020), PROVEAN (http:/ / provean.jcvi.org/index.php, accessed on 1 September 2020) and ExPASy (https://web.expasy.org/protscale/, accessed on 1 September 2020) tools, which provided the estimation of the putative pathogenic nature, as benign or possibly damaging. Protein structure predictions were carried out by Raptor $X$ (http:/ / raptorx.uchicago.edu/, accessed on 1 September 2020), and the structures of the PSEN1 Val96Phe variant were compared to the normal X-ray structure [12]. Superimposed images of variant and normal proteins were aligned by Discovery Studio 3.5 Visualizer software (designed by Accerlrys Inc., San Diego, CA, USA).

\section{Results}

\subsection{Subjects}

Two Malaysian siblings (III-2, III-3) were affected with memory loss at the age of 48 and 44 years, respectively. Family history of AD was positive in this family. The eldest sister 
(III-1) developed AD at 50 years of age but could not be genotyped. Two younger siblings (III-4, III-5) aged 39 and 35 years were asymptomatic at the time of reporting. Clinical phenotype of grandparents (I-1, I-2) remained unclear. The father (II-1) and paternal aunt (II-3) developed dementia at 57 and 50 years, respectively. The paternal aunt (II-3) has nine children, ages ranged from 30-54 years, all of whom were asymptomatic at the time of reporting (Figure 1 and Table 1). Detailed clinical description was provided on III-3 and III-4 patients. Both patients carried the E3/E4 genotype for apolipoprotein E (APOE).

I.

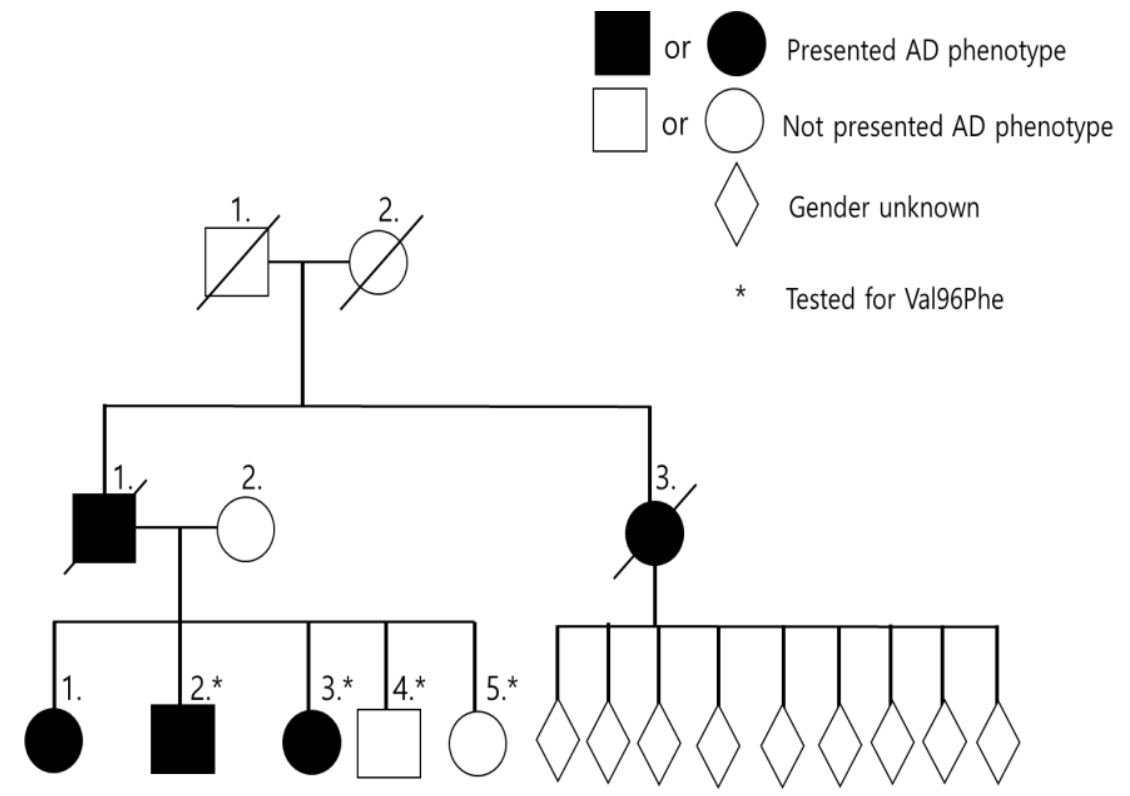

II.

Figure 1. Family tree of Malaysian family.

Table 1. Clinical details of Malaysian family with EOAD.

\begin{tabular}{|c|c|c|c|c|c|c|c|}
\hline & Age of Onset & Memory Loss & $\begin{array}{l}\text { Cognitive } \\
\text { Deficits }\end{array}$ & $\begin{array}{l}\text { Deficits in Spatial } \\
\text { Awareness }\end{array}$ & $\begin{array}{c}\text { Behavioral and } \\
\text { Personality Change }\end{array}$ & Seizures & $\begin{array}{c}\text { V96F } \\
\text { Mutation }\end{array}$ \\
\hline II-1 & 57 & + & + & + & + & - & NA \\
\hline III-3 & 50 & + & + & + & + & - & NA \\
\hline III-1 & 50 & + & + & - & - & - & NA \\
\hline III-2 & 48 & + & + & + & + & + & Positive \\
\hline III-3 & 44 & + & + & - & + & - & Positive \\
\hline III-4 & No symptoms & - & - & - & - & - & Positive \\
\hline III-5 & No symptoms & - & - & - & - & - & Negative \\
\hline
\end{tabular}

Patient III-2 experienced medical decline at the age of 47 years. He visited the clinic at the age of 49 years, with no background medical illness. His wife noted that he had shortterm memory loss, repeated himself often, and was unable to pay utility bills. The patient also frequently lost items, such as glasses or phone, and had difficulties in driving. He also resigned from his office job related to sales due to stress. At the age of 48 years, speech impairment appeared such as paucity of speech, naming his children, and describing the weather. In addition, he was unable to pronounce words clearly or speak in full sentences. His MMSE on presentation was 16/30. His initial investigations showed normal full blood count, liver and renal function, $\mathrm{HbA} 1 \mathrm{c}$ and $\mathrm{B} 12$ level, mildly elevated total cholesterol of $5.9 \mathrm{mmol} / \mathrm{L}$, and low folate of $9 \mathrm{nmol} / \mathrm{L}(12-44 \mathrm{nmol} / \mathrm{L})$. The initial CT brain showed mild cerebral atrophy with no evidence of cerebral infarctions. The MRI brain revealed mild generalized cerebral volume loss prominently involving the temporal and parietal lobes with profound diffuse volume loss over bilateral hippocampal formations and mild 
volume loss of the parahippocampal gyri. He was prescribed a rivastigmine patch and folate supplements. No leukodystrophy, white matter changes, microbleeds, or cerebral amyloid angiopathy were observed in his brain (Figure 2). A year after the first visit, the patient did not recognize his children and wife, and his speech was no longer meaningful. He started to have repetitive behaviour, motor and sleep disturbances, as well as aggression. He developed apraxia, agnosia, and aphasia. He required help in bathing, dressing, or going to the washroom. His MMSE dropped within a year from 16 to 7 . Medications were changed to memantine and donepezil. Two years into follow-up, at the age of 51, he was completely dependent in his activities of daily living. He developed one episode of seizure requiring admission. His MMSE score was 1/30.

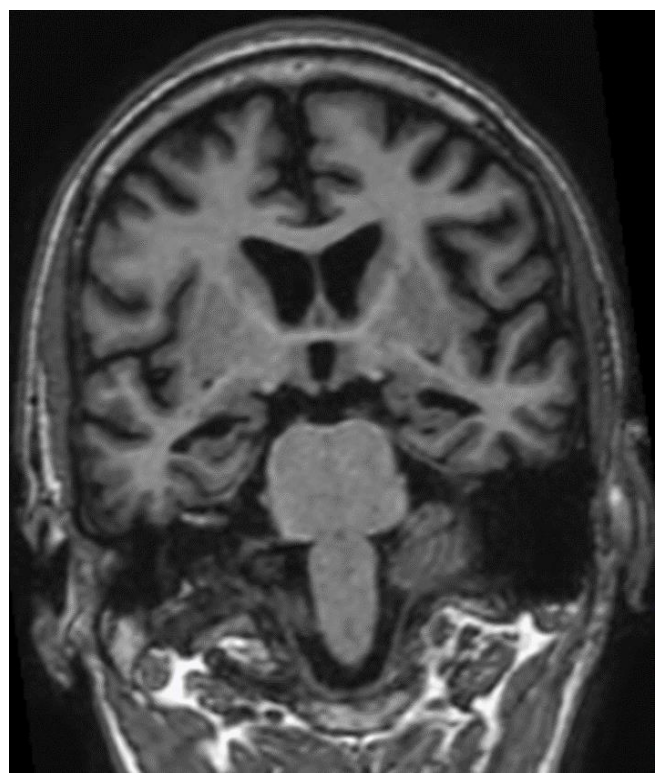

(a)

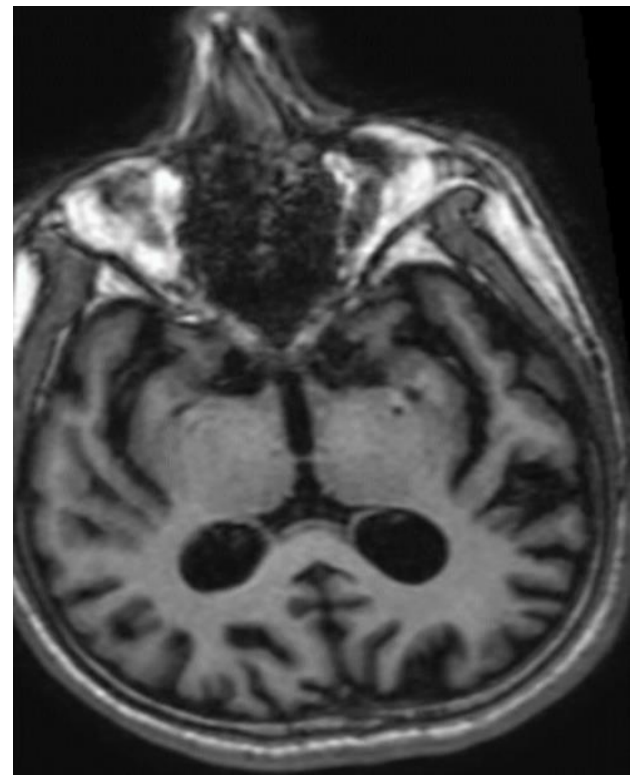

(b)

Figure 2. (a) Coronal T1W MP RAGE image of brain shows atrophy of bilateral hippocampi, more pronounced on the right side. Widening of the cerebral sulci predominantly in the temporal lobes and both lateral ventricles are also noted. (b) Axial T1W MP RAGE image of the brain shows widening of bilateral Sylvian fissure. Dilated occipital horn of both ventricles is also noted.

Patient III-3 was first seen at the clinic at age 44 years due to the suspicion of familial early onset Alzheimer's dementia. She was still working as an office assistant in tax department; however, she was having problems making entries into the computer, and was thus assigned simple tasks such as putting letters into envelopes. She was still able to cook and do house chores but frequently forgot where she put her things. She was no longer able to handle home finances. Her physical examination was unremarkable and her MMSE was 18/30. She had normal full blood count, renal and liver function, calcium, phosphate, $\mathrm{HbA1c}$, thyroid function, cholesterol, and B12 levels. Her folate levels were low at 6.16 $\mathrm{nmol} / \mathrm{L}(12-44 \mathrm{nmol} / \mathrm{L})$. Her MRI brain showed mild reduction in right hippocampal volume, with normal left hippocampus. An asymmetrical hippocampal volume with prominent parietal sulci and ambient cistern is suggestive of early Alzheimer's disease. She was started on rivastigmine. A year into follow-up, she was still able to work and do house chores but was unable to remember details regarding her children's education and work. She started developing aggressive behavior and psychotic symptoms. Eating disturbances also appeared in her, and she often refused all food and drink. She also had frequent sleep disturbances. Her MMSE scores declined from 18/30 to 13/30. Rivastigmine was changed to donezepil. Risperidone was started for control of her psychotic symptoms. Two years into follow-up, she was no longer able to work, cook, or do housework and required supervision for showering and dressing. Three years into follow-up, at the age of 47 years, she was fully dependent on her husband and had very limited language. She was 
still able to move independently, mostly wandering around the house aimlessly. MMSE was reduced to $1 / 30$. Memantine was added to her medications.

\subsection{Genetic and Structure Findings}

A pathogenic G>T exchange was found in PSEN1 exon 4 in all two siblings (c.286G $>$ T, III-2, III-3), resulting in valine (Val) to phenylalanine (Phe) exchange at codon 96 (p.Val96Phe, Figure 3). Two asymptomatic siblings were tested too, and III-4 was positive for mutation, but III-5 was negative (Supplementary Figure S1). According to KRGDB database, the mutation was missing among 1100 unaffected Korean individuals. It was neither observed in 1000Genomes nor in GnomAD databases. PolyPhen and SIFT tools predicted the mutation as probably damaging with the score of 1.0 and 0.002 , respectively. Multiple sequence alignment by Polyphen2 tool revealed that PSEN1 Val96 may be a conservative residue between different species, since valine was detected in the same residue in the PSEN-like sequence of other animal species. PROVEAN also predicted the mutation as deleterious with the score of -4.643 . ExPASY revealed higher hydrophobicity scores for Phe (Val: 0.6; Phe: 0.712 , Figure $4 a$ ). The polarity score for Phe was slightly reduced in comparison to Val (Val: 6.3; Phe: 6.222, Figure 4b).

Mutation is located in the first TM helix of PSEN1 protein. Structure predictions revealed the putative disturbances in Helix-I (Figure 5a). Even though both Val and Phe are non-polar amino acids, the slightly higher hydrophobic property of Phe may disturb the helix motion and dynamics of PSEN1. The larger size of benzyl group in Phe may also result in extra stress inside the Helix-I.

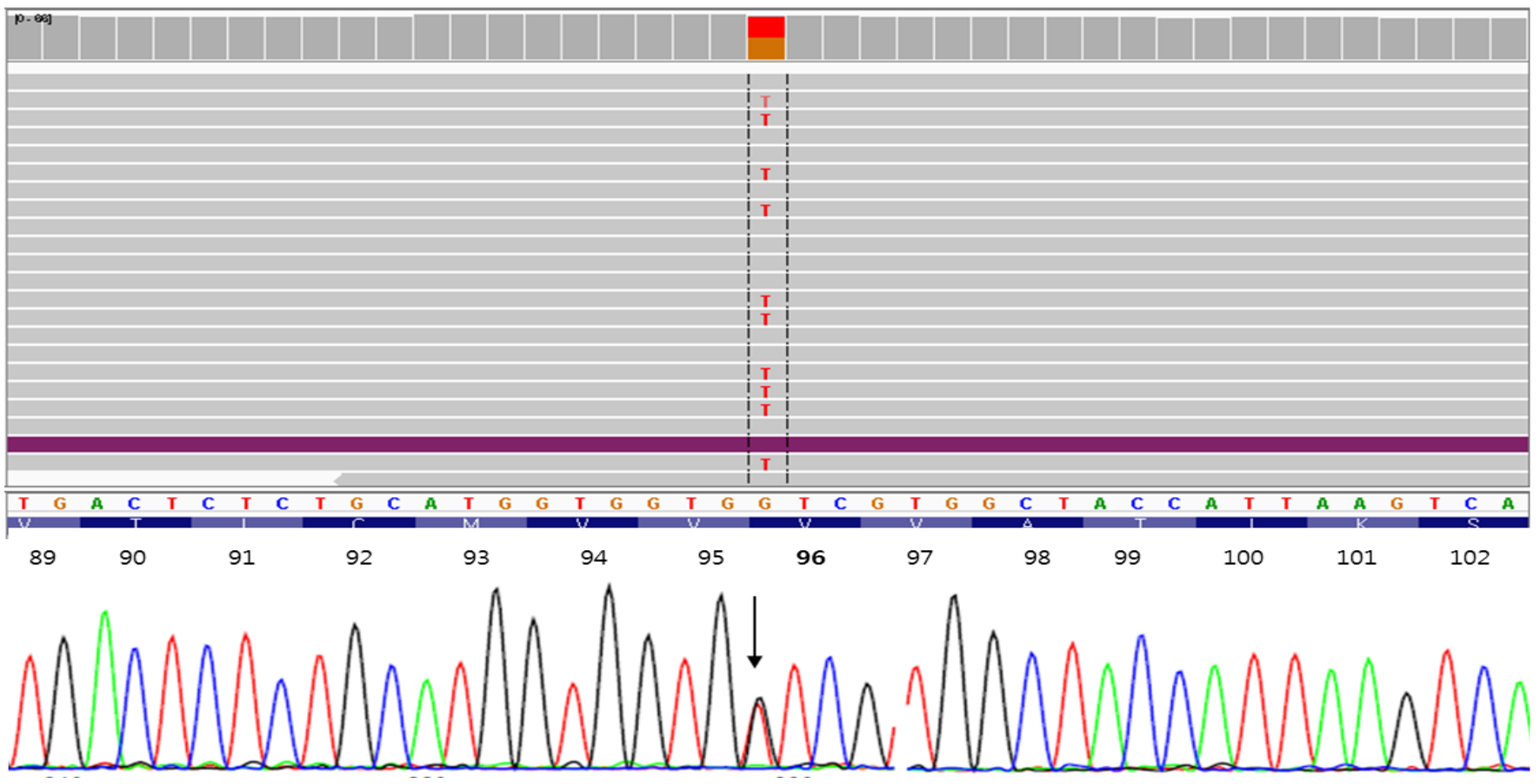

Figure 3. Whole-exome sequencing data of PSEN1 Val96Phe mutation. 


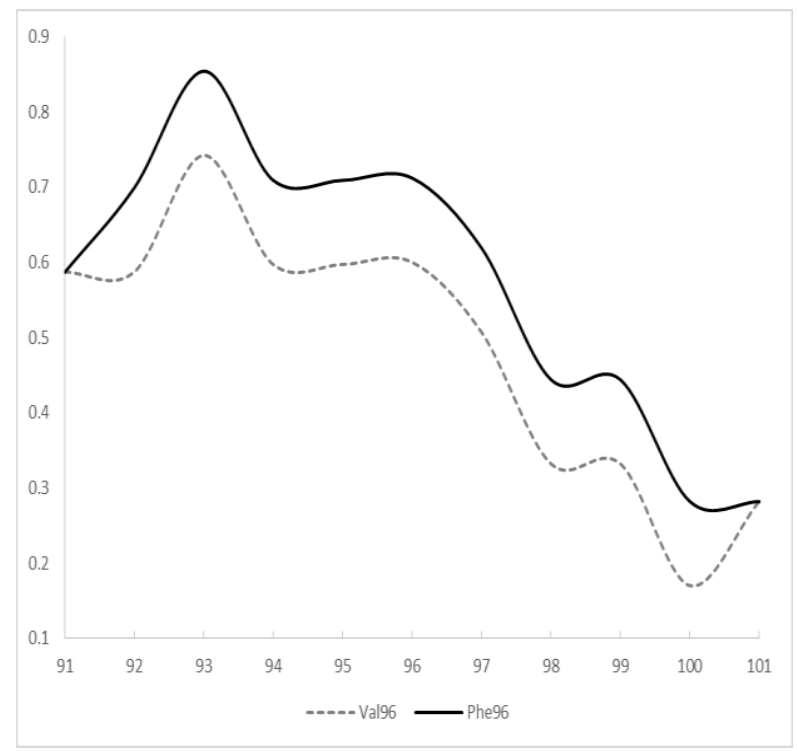

(a)

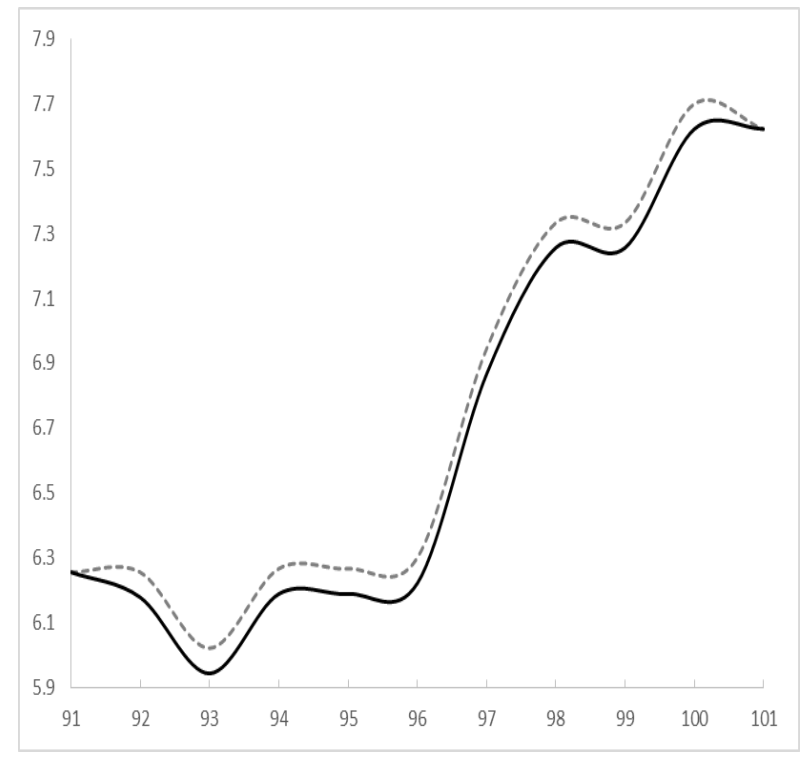

(b)

Figure 4. ExPASY prediction on PSEN1 Val96Phe mutation (a) hydrophobicity scores and (b) polarity scores.

a.

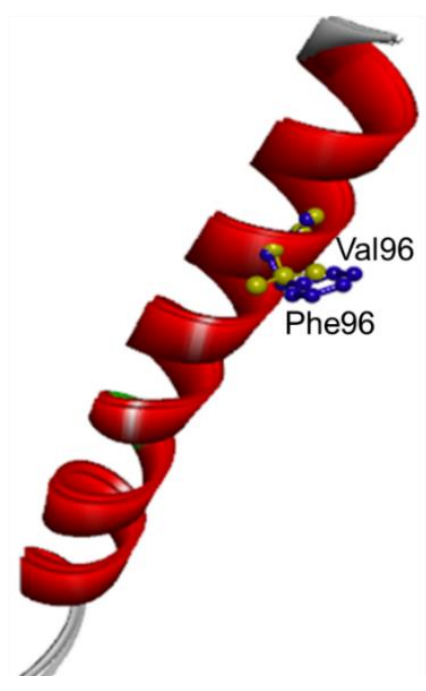

b.

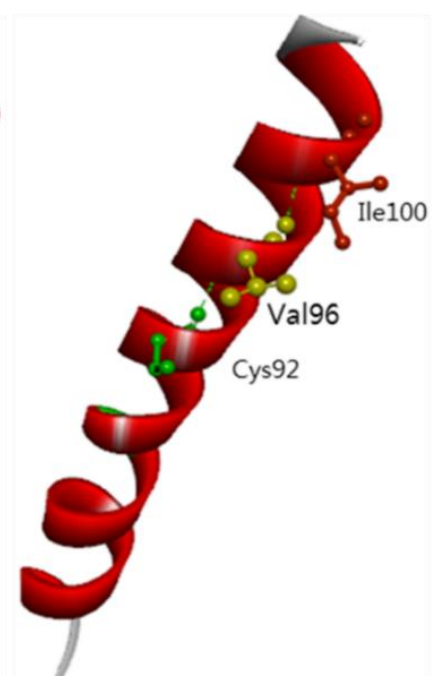

c.

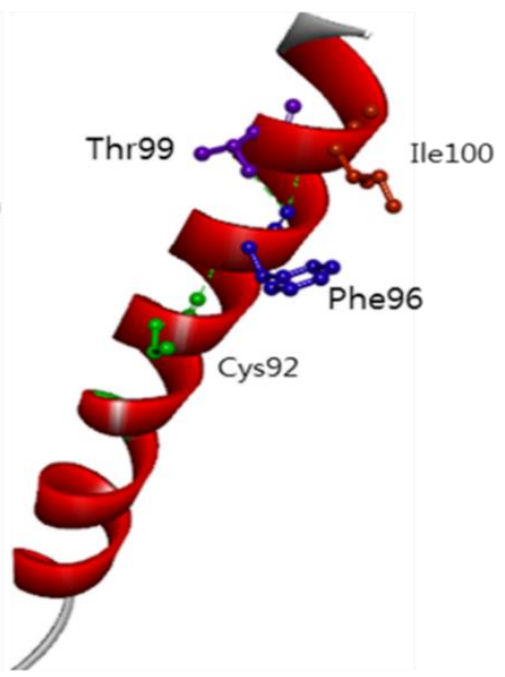

Figure 5. (a) 3D model on PSEN1 Va196Phe mutation, compared to the normal PSEN1 protein. (b) Intramolecular interactions in PSEN1 Val96. (c) Intramolecular interaction for PSEN1 Phe96.

Intramolecular interactions may also be changed due to PSEN1 Va196Phe mutation. Val96 could form a hydrogen bond with Ile100 and Cys92 (Figure 5b). In the case of Phe96, interactions with Cys remained, but an additional hydrogen bond may be seen with Thr99 (Figure 5c). This putative novel hydrogen bond may result in limited helix motion, which could possibly affect the PSEN1 function. The intra-helical interactions inside TM-I may be stronger due to the mutation, which could potentially result in extra stress in the helix. In addition, it may also disturb the interactions between TM-I and additional TM domains inside PSEN1.

\section{Discussion}

We reported a known pathogenic PSEN1 mutation, p.Val96Phe, in a Malaysian family. The family history strongly suggested it to be autosomal dominant, since two siblings (III-2 and III-3) with the mutation were diagnosed with EOAD. In addition, their elder sister 
(III-1), father (II-1), and aunt (II-3) also developed cognitive-and memory dysfunctions. Their younger brother (III-4) also carried the mutation, but he did not develop any disease phenotype yet. He is most likely in pre-symptomatic stage currently. PSEN1 Val96Phe was reported previously as a pathogenic mutation in a Japanese family. All affected family members from Japan were diagnosed with EOAD, and the symptoms appeared between 49 and 60 years of age. No detailed clinical description was presented in the previous report from Japan. However, the mutation was segregated with the disease, which was missing in 100 control individuals in Japan [8]. PSEN1 Val96Phe was also missing in different reference databases (GnomAD or 1000Genomes), which may also further prove its absence in unaffected individuals. Both Malaysian and Japanese cases were associated with familial EOAD with a similar age of onset. Mutation was with cloned COS-1 cell line. The elevated $A \beta \beta 42 /$ total $A \beta$ (1.6 times) levels suggested that the mutation could enhance gamma secretase activity, resulting in elevated $A \beta 42$ levels [13,14].

PSEN1 Val96Phe is in the first transmembrane domain (TM1) in PSEN1 protein. Several pathogenic mutations were discovered in the TM1 of PSEN1 (Table 2, Figure 6). The age of onset associated with these mutations in TMI could be variable. The majority of patients with the mutations reported the age of onset in their 40s or 50s [15]. In addition, several mutations were associated with younger onset AD, such as PSEN1 Leu85Pro [16], Pro88Leu [17], Val89Leu [18], and Val97Leu [19]. All patients with these mutations were diagnosed with EOAD. Patients with Val82Leu [20], Val96Phe [8], or Thr99Ala [21] mutations presented typical EOAD symptoms. Other clinical symptoms could also appear, such as behavioral/psychiatric symptoms for patients with Ile83Thr [22], Met84Val [23], or Val89Leu [18] mutations. Spastic paraparesis were prominent for patients with Ile83Thr [22], del_Ile83/Met84 [24,25], or Leu85Pro [16]. Parkinsonism was also discovered in patients with Pro88Leu [17] or Cys92Ser [26]. The following mutations, del_Ile83/Met84 [24,25], Leu85Pro [16], Val96Phe [8,13], Val97Leu [19,27], were transfected into cells for the verification of their pathogenicity. Interestingly, the cloned Val82Leu mutation into $\mathrm{CHO}$ cells revealed reduced $A \beta 42$ levels, suggesting its participation in the pathogenic mechanisms [28].

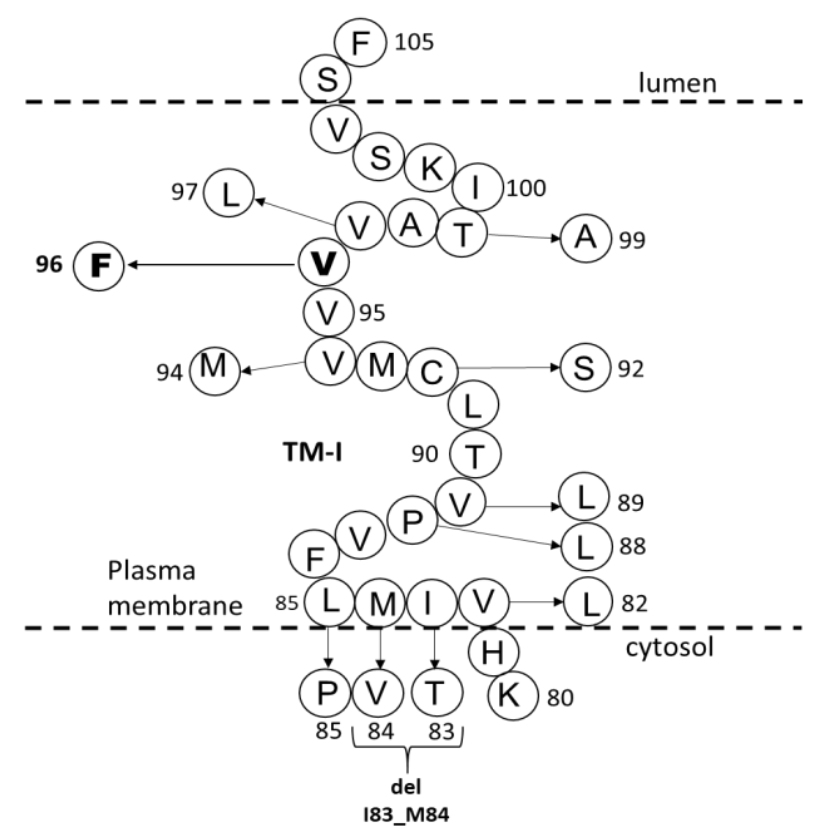

Figure 6. Mutations located in the TM-I of PSEN1. Mutations in TM-I may result in dysfunctions in $\gamma$-secretase cleavage by altering the intra-and intermolecular interactions of PSEN1. 
Table 2. Mutations, described in TM-I domain of PSEN1. Majority of mutations were associated with relatively young onset and positive family history of disease.

\begin{tabular}{|c|c|c|c|c|c|}
\hline Mutation & Clinical Symptoms & Age of Onset (Year) & Family History & Functional Studies & References \\
\hline Val82Leu & EOAD & $53-58$ & $\begin{array}{c}\text { Positive } \\
\text { (2 French family) }\end{array}$ & $\begin{array}{c}\text { HEK293: } 1.5 \text { times } \\
\text { elevated A } \beta 42 / \mathrm{A} \beta 40 \\
\text { CHO: } 1.4 \text { times } \\
\text { reduced } \\
\text { CHO-APP695 }\end{array}$ & [20] \\
\hline Ile83Thr & $\begin{array}{c}\text { EOAD, behavioral } \\
\text { symptoms, } \\
\text { depression, } \\
\text { hallucinations }\end{array}$ & $55-64$ & $\begin{array}{l}\text { Probable positive } \\
\text { (Tunisian) }\end{array}$ & NA & [22] \\
\hline del_Ile83/Met84 & $\begin{array}{l}\text { EOAD, spastic } \\
\text { paraparesis, cotton } \\
\text { wool plaques, } \\
\text { cerebral amyloid } \\
\text { antipathy }\end{array}$ & $34-38$ & $\begin{array}{l}\text { Positive } \\
\text { (Scottish) }\end{array}$ & $\begin{array}{c}\text { HEK293: } 4.8 \text { times } \\
\text { elevated A } \beta 42 / \mathrm{A} \beta 40 \\
\text { H4: } 2.6 \text { times higher } \\
\text { A } \beta 42 / \mathrm{A} \beta 40\end{array}$ & {$[24,25]$} \\
\hline Met84Val & $\begin{array}{l}\text { EOAD, psychotic } \\
\text { symptoms }\end{array}$ & $49-57$ & $\begin{array}{l}\text { Positive } \\
\text { (Italian) }\end{array}$ & NA & {$[23,29]$} \\
\hline Leu85Pro & $\begin{array}{l}\text { EOAD, spastic } \\
\text { paraparesis }\end{array}$ & 26 & $\begin{array}{l}\text { De novo } \\
\text { (Japan) }\end{array}$ & $\begin{array}{l}\text { HEK293: } 1.9 \text { times } \\
\text { elevated } A \beta 42 / A \beta 40\end{array}$ & [16] \\
\hline Pro88Leu & $\begin{array}{l}\text { EOAD, myoclonus, } \\
\text { Parkinsonism, } \\
\text { apraxia }\end{array}$ & $20 \mathrm{~s}$ & $\begin{array}{l}\text { Unknown } \\
\text { (China) }\end{array}$ & $\begin{array}{l}\text { Increased the long } \\
\text { amyloid peptides }\end{array}$ & [17] \\
\hline $\begin{array}{l}\text { Val89Leu } \\
\text { G }>C\end{array}$ & EOAD & Late $30 \mathrm{~s}$ & $\begin{array}{l}\text { Unknown } \\
\text { (China) }\end{array}$ & NA & [24] \\
\hline $\begin{array}{c}\text { Val89>Leu } \\
\text { G }>\text { T }\end{array}$ & $\begin{array}{c}\text { EOAD with } \\
\text { personality changes }\end{array}$ & $46-51$ & $\begin{array}{l}\text { Familial } \\
\text { (Spain) }\end{array}$ & NA & [18] \\
\hline Cys92Ser & $\begin{array}{l}\text { EOAD, parkinsonism, } \\
\text { hallucination }\end{array}$ & $49-70$ & $\begin{array}{c}\text { Familial } \\
\text { (Italy) }\end{array}$ & $\begin{array}{c}\text { Fibroblast cells: } \\
\text { elevated } A \beta 42 \text { levels }\end{array}$ & [26] \\
\hline Val94Met & EOAD & 53 & $\begin{array}{c}\text { De novo } \\
\text { (Columbia) }\end{array}$ & NA & [30] \\
\hline Val96Phe & EOAD & $44-57$ & $\begin{array}{c}\text { Familial } \\
\text { (Japan, Malaysia) }\end{array}$ & $\begin{array}{c}\text { elevated } \\
A \beta 42 / \text { totalA } \beta \text { in } \\
\text { COS1 cells }\end{array}$ & {$[8,13]$, our case } \\
\hline Va197Leu & EOAD & Late 30 s, early 40 s & $\begin{array}{l}\text { Familial } \\
\text { (China) }\end{array}$ & $\begin{array}{c}\text { SH-SY5Y cells: } \\
\text { elevated intracellular } \\
\text { and extracellular } \\
\text { A } \beta 42\end{array}$ & {$[19,27]$} \\
\hline Thr99Ala & EOAD & 43 & $\begin{array}{l}\text { De novo } \\
\text { (Japan) }\end{array}$ & NA & [21] \\
\hline
\end{tabular}

TM-I domain was found to be relatively conservative between PSEN1 and PSEN2 for its critical role in $\gamma$-secretase activity. Hence, even slight alterations of structure might have larger effects in A $\beta$ metabolism. Experiments of deleting TM-I and TM-II domains or the connecting loop (HL-I) in PSEN1 (Val82-Tyr154) could affect the endoproteolysis of PSEN1, affecting the APP metabolism. The deletion of these domains may result in the accumulation of CTF fragment of APP by delayed $\gamma$-secretase processing. A loss of PSEN1 function may also impair the APP trafficking. In addition, the deletion of TM1-HLI-TMII region may also impair the Notch signaling [31,32]. Structure predictions by Queralt et al. (2002) revealed that in normal PSEN1 protein, valine residues in TM-I may be in contact with the hydrophobic residues in TM-VII. Mutations in TM-I may increase the distance between TM-I and TM-VII, resulting in additional stress inside the PSEN1 protein [18]. All of these findings suggested that mutations in the TM-I may be responsible pathogenic mutations in EOAD. Cell studies from different mutations (including Val96Phe) suggested that TM-I may play a significant role in APP trafficking and amyloid peptide cleavage. 


\section{Conclusions}

In this study, a pathogenic PSEN1 mutation, Val96Phe, was described in a Malaysian family. The mutation was initially discovered in a Japanese family in 1996. The Malaysian case revealed a strong family history of disease, since at least two family members with EOAD carried the mutation, and other relatives were affected with EOAD. This report may add additional clinical details, associated with AD patients, binding PSEN1 Val96Phe mutation. This is a second pathogenic PSEN1 mutation, which was described in a Malaysian family [33]. Due to the algorithm of Guerreiro et al. (2010) PSEN1 Val96Phe is a pathogenic mutation. The mutation was missing in different reference databases (1000Genomes, Gno$\mathrm{mAD}$ ), suggesting that it may not be present in individuals without any neurodegenerative disease. Multiple sequence alignment revealed that Val96 is a conservative residue among vertebrates. Additionally, PSEN1 Va196Phe is located in a region which was verified as conservative between PSEN1 and PSEN2 [34]. In addition, PSEN1 Val96Phe appeared in patients from two independent families affected with EOAD [34]. Our in silico prediction suggested that mutation could possibly disturb the intramolecular interactions inside the PSEN1. In addition, it could probably result in abnormalities in PSEN1 and $\gamma$-secretase functions by resulting in stress between PSEN1 TM-I and TM-VIII. Mutations in TM-I could also potentially affect the endoproteolysis of PSEN1 protein, resulting in disturbances in APP cleavage, and elevated A $\beta 42$ productions [31,32]. The limitations of this study were that we were unable to perform cerebrospinal fluid (CSF) amyloid biomarker study since patients refused CSF analysis. Additionally, full segregation analysis could not be performed since several affected family members passed away and/or no sample was available from them. Additionally, the currently asymptomatic cousins of the patient refused the genetic test. Furthermore, no in vitro study was performed on this mutation by our group. However, in the future, we will perform in vitro analyses on the mutation in additional cell lines, such as HEK-293.

Supplementary Materials: The following are available online at https:/ /www.mdpi.com/article/10 .3390/brainsci11101328/s1, Figure S1: Sequencing data of family members, Table S1: Genes, involved in the gene panel, Table S2: (a). Variants, found in III-3 (b). variants found in III-4.

Author Contributions: Conceptualization: all authors; methodology, E.B., G.-S.C.; software, E.B.; validation, G.-S.C., M.-Y.C. formal analysis, E.B., G.-S.C., M.-Y.C.; investigation G.-S.C., S.S.A.A., S.K.; re-sources, S.S.A.A., G.-S.C.; data curation, S.K., S.S.A.A.; writing—original draft preparation, E.B., M.-Y.C., G.-S.C.; writing—review and editing, S.S.A.A., S.K.; visualization, all authors.; supervision, S.K., S.S.A.A.; project administration, S.K., S.S.A.A.; funding acquisition, S.S.A.A. All authors have read and agreed to the published version of the manuscript.

Funding: This research was funded by the National Research Foundation of Korea (NRF) by the Korean government (2020R1A2B5B01002463); and by Basic Science Research Program through the National Research Foundation of Korea (NRF) funded by the Ministry of Education (2021R1A6A1A03038996).

Institutional Review Board Statement: This research was approved by Internal Review Board at Gachon University, Seongnam, Republic of Korea (1044396-202108-HR-184-01).

Informed Consent Statement: Diagnosis of probable AD was carried out, according to the criteria of the National Institute of Neurological and Communicative Disorders and Stroke Alzheimer' Disease and Related Disorders Association.

Data Availability Statement: Data available on request due to restrictions eg privacy or ethical.

Acknowledgments: Authors would like to express their gratitude to the proband patients and their family members for their time and support.

Conflicts of Interest: The authors declare no conflict of interest. The funders had no role in the design of the study; in the collection, analyses, or interpretation of data; in the writing of the manuscript, or in the decision to publish the results. 


\section{References}

1. van der Flier, W.M. Clinical heterogeneity in familial Alzheimer's disease. Lancet Neurol. 2016, 15, 1296-1298. [CrossRef]

2. Ryman, D.C.; Acosta-Baena, N.; Aisen, P.S.; Bird, T.; Danek, A.; Fox, N.C.; Goate, A.; Frommelt, P.; Ghetti, B.; Langbaum, J.B.; et al. Symptom onset in autosomal dominant Alzheimer disease: A systematic review and meta-analysis. Neurology 2014, 83, 253-260. [CrossRef] [PubMed]

3. Borchelt, D.R.; Thinakaran, G.; Eckman, C.B.; Lee, M.K.; Davenport, F.; Ratovitsky, T.; Prada, C.M.; Kim, G.; Seekins, S.; Yager, D.; et al. Familial Alzheimer's disease-linked presenilin 1 variants elevate Abeta1-42/1-40 ratio in vitro and in vivo. Neuron 1996, 17, 1005-1013. [CrossRef]

4. Bagyinszky, E.; Youn, Y.C.; An, S.S.; Kim, S. The genetics of Alzheimer's disease. Clin. Interv. Aging 2014, 9, 535-551. [CrossRef]

5. Xia, D.; Watanabe, H.; Wu, B.; Lee, S.H.; Li, Y.; Tsvetkov, E.; Bolshakov, V.Y.; Shen, J.; Kelleher, R.J., 3rd. Presenilin-1 knockin mice reveal loss-of-function mechanism for familial Alzheimer's disease. Neuron 2015, 85, 967-981. [CrossRef] [PubMed]

6. Ikeda, M.; Sharma, V.; Sumi, S.M.; Rogaeva, E.A.; Poorkaj, P.; Sherrington, R.; Nee, L.; Tsuda, T.; Oda, N.; Watanabe, M.; et al. The clinical phenotype of two missense mutations in the presenilin I gene in Japanese patients. Ann. Neurol. 1996, 40, 912-917. [CrossRef]

7. Tanahashi, H.; Kawakatsu, S.; Kaneko, M.; Yamanaka, H.; Takahashi, K.; Tabira, T. Sequence analysis of presenilin-1 gene mutation in Japanese Alzheimer's disease patients. Neurosci. Lett. 1996, 218, 139-141. [CrossRef]

8. Kamino, K.; Sato, S.; Sakaki, Y.; Yoshiiwa, A.; Nishiwaki, Y.; Takeda, M.; Tanabe, H.; Nishimura, T.; Ii, K.; George-Hyslop, P.H.S.; et al. Three different mutations of presenilin 1 gene in early-onset Alzheimer's disease families. Neurosci. Lett. 1996, 208, 195-198. [CrossRef]

9. Giau, V.V.; Bagyinszky, E.; Youn, Y.C.; An, S.S.A.; Kim, S. APP, PSEN1, and PSEN2 Mutations in Asian Patients with Early-Onset Alzheimer Disease. Int. J. Mol. Sci. 2019, 20, 4757. [CrossRef]

10. McKhann, G.; Drachman, D.; Folstein, M.; Katzman, R.; Price, D.; Stadlan, E.M. Clinical diagnosis of Alzheimer's disease, Report of the NINCDS-ADRDA Work Group * under the auspices of Department of Health and Human Services Task Force on Alzheimer's Disease. Neurology 1984, 34, 939. [CrossRef] [PubMed]

11. van Giau, V.; An, S.S.A.; Bagyinszky, E.; Kim, S. Gene panels and primers for next generation sequencing studies on neurodegenerative disorders. Mol. Cell. Toxicol. 2015, 11, 89-143. [CrossRef]

12. Källberg, M.; Wang, H.; Wang, S.; Peng, J.; Wang, Z.; Lu, H.; Xu, J. Template-based protein structure modeling using the RaptorX web server. Nat. Protoc. 2012, 7, 1511-1522. [CrossRef] [PubMed]

13. Murayama, O.; Tomita, T.; Nihonmatsu, N.; Murayama, M.; Sun, X.; Honda, T.; Iwatsubo, T.; Takashima, A. Enhancement of amyloid beta 42 secretion by 28 different presenilin 1 mutations of familial Alzheimer's disease. Neurosci. Lett. 1991, $265,61-63$. [CrossRef]

14. Leem, J.Y.; Saura, C.A.; Pietrzik, C.; Christianson, J.; Wanamaker, C.; King, L.T.; Veselits, M.L.; Tomita, T.; Gasparini, L.; Iwatsubo, T.; et al. A role for presenilin 1 in regulating the delivery of amyloid precursor protein to the cell surface. Neurobiol. Dis. 2002, 11, 64-82. [CrossRef] [PubMed]

15. Bagyinszky, E.; Youn, Y.C.; An, S.S.; Kim, S. Mutations, associated with early-onset Alzheimer's disease, discovered in Asian countries. Clin. Interv. Aging 2016, 11, 1467-1488. [CrossRef]

16. Ataka, S.; Tomiyama, T.; Takuma, H.; Yamashita, T.; Shimada, H.; Tsutada, T.; Kawabata, K.; Mori, H.; Miki, T. A novel presenilin-1 mutation (Leu85Pro) in early-onset Alzheimer disease with spastic paraparesis. Arch. Neurol. 2004, 61, 1773-1776. [CrossRef]

17. Liu, C.Y.; Ohki, Y.; Tomita, T.; Osawa, S.; Reed, B.R.; Jagust, W.; Van Berlo, V.; Jin, L.W.; Chui, H.C.; Coppola, G.; et al. Two Novel Mutations in the First Transmembrane Domain of Presenilin1 Cause Young-Onset Alzheimer's Disease. J. Alzheimers Dis. 2017, 58, 1035-1041. [CrossRef]

18. Queralt, R.; Ezquerra, M.; Lleó, A.; Castellví, M.; Gelpí, J.; Ferrer, I.; Acarín, N.; Pasarín, L.; Blesa, R.; Oliva, R. A novel mutation (V89L) in the presenilin 1 gene in a family with early onset Alzheimer's disease and marked behavioural disturbances. J. Neurol. Neurosurg. Psychiatry 2002, 72, 266-269. [CrossRef]

19. Jia, J.; Xu, E.; Shao, Y.; Jia, J.; Sun, Y.; Li, D. One novel presenilin-1 gene mutation in a Chinese pedigree of familial Alzheimer's disease. J. Alzheimers Dis. 2005, 7, 119-124, discussion 173-80. [CrossRef]

20. Campion, D.; Flaman, J.M.; Brice, A.; Hannequin, D.; Dubois, B.; Martin, C.; Moreau, V.; Charbonnier, F.; Didierjean, O.; Tardieu, S. Mutations of the presenilin I gene in families with early-onset Alzheimer's disease. Hum. Mol. Genet. 1995, 4, $2373-2377$. [CrossRef] [PubMed]

21. Ikeda, M.; Yonemura, K.; Kakuda, S.; Tashiro, Y.; Fujita, Y.; Takai, E.; Hashimoto, Y.; Makioka, K.; Furuta, N.; Ishiguro, K.; et al. Cerebrospinal fluid levels of phosphorylated tau and A $\beta 1-38 / A \beta 1-40 / A \beta 1-42$ in Alzheimer's disease with PS1 mutations. Amyloid 2013, 20, 107-112. [CrossRef]

22. Achouri-Rassas, A.; Ben Ali, N.; Fray, S.; Hadj Fredj, S.; Kechaou, M.; Zakraoui, N.O.; Cherif, A.; Chabbi, S.; Anane, N.; Messaoud, T.; et al. Novel presenilin 1 mutation (p.I83T) in Tunisian family with early-onset Alzheimer's disease. Neurobiol. Aging 2015, 36, e9-e11. [CrossRef]

23. Hooli, B.V.; Kovacs-Vajna, Z.M.; Mullin, K.; Blumenthal, M.A.; Mattheisen, M.; Zhang, C.; Lange, C.; Mohapatra, G.; Bertram, L.; Tanzi, R.E. Rare autosomal copy number variations in early-onset familial Alzheimer's disease. Mol. Psychiatry 2014, 19, 676-681. [CrossRef] [PubMed] 
24. Houlden, H.; Baker, M.; McGowan, E.; Lewis, P.; Hutton, M.; Crook, R.; Wood, N.W.; Kumar-Singh, S.; Geddes, J.; Swash, M.; et al. Variant Alzheimer's disease with spastic paraparesis and cotton wool plaques is caused by PS-1 mutations that lead to exceptionally high amyloid-beta concentrations. Ann. Neurol. 2000, 48, 806-808. [CrossRef]

25. Steiner, H.; Revesz, T.; Neumann, M.; Romig, H.; Grim, M.G.; Pesold, B.; Kretzschmar, H.A.; Hardy, J.; Holton, J.L.; Baumeister, R.; et al. A pathogenic presenilin-1 deletion causes abberrant Abeta 42 production in the absence of congophilic amyloid plaques. $J$. Biol. Chem. 2001, 276, 7233-7239. [CrossRef]

26. Tedde, A.; Nacmias, B.; Ciantelli, M.; Forleo, P.; Cellini, E.; Bagnoli, S.; Piccini, C.; Caffarra, P.; Ghidoni, E.; Paganini, M.; et al. Identification of new presenilin gene mutations in early-onset familial Alzheimer disease. Arch. Neurol. 2003, 60, 1541-1544. [CrossRef] [PubMed]

27. Fang, B.; Jia, L.; Jia, J. Chinese Presenilin-1 V97L mutation enhanced Abeta42 levels in SH-SY5Y neuroblastoma cells. Neurosci. Lett. 2006, 406, 33-37. [CrossRef]

28. Shioi, J.; Georgakopoulos, A.; Mehta, P.; Kouchi, Z.; Litterst, C.M.; Baki, L.; Robakis, N.K. FAD mutants unable to increase neurotoxic Abeta 42 suggest that mutation effects on neurodegeneration may be independent of effects on Abeta. J. Neurochem. 2007, 101, 674-681. [CrossRef]

29. Gallo, M.; Frangipane, F.; Cupidi, C.; De Bartolo, M.; Turone, S.; Ferrari, C.; Nacmias, B.; Grimaldi, G.; Laganà, V.; Colao, R.; et al. The novel PSEN1 M84V mutation associated to frontal dysexecutive syndrome, spastic paraparesis, and cerebellar atrophy in a dominant Alzheimer's disease family. Neurobiol. Aging 2017, 56, 213-e7. [CrossRef]

30. Arango, D.; Cruts, M.; Torres, O.; Backhovens, H.; Serrano, M.L.; Villareal, E.; Montañes, P.; Matallana, D.; Cano, C.; Van Broeckhoven, C.; et al. Systematic genetic study of Alzheimer disease in Latin America: Mutation frequencies of the amyloid beta precursor protein and presenilin genes in Colombia. Am. J. Med. Genet. 2001, 103, 138-143. [CrossRef]

31. Gong, P.; Vetrivel, K.S.; Nguyen, P.D.; Meckler, X.; Cheng, H.; Kounnas, M.Z.; Wagner, S.L.; Parent, A.T.; Thinakaran, G. Mutation analysis of the presenilin $1 \mathrm{~N}$-terminal domain reveals a broad spectrum of gamma-secretase activity toward amyloid precursor protein and other substrates. J. Biol. Chem. 2010, 285, 38042-38052. [CrossRef] [PubMed]

32. Szaruga, M.; Munteanu, B.; Lismont, S.; Veugelen, S.; Horré, K.; Mercken, M.; Saido, T.C.; Ryan, N.S.; De Vos, T.; Savvides, S.N.; et al. Alzheimer's-Causing Mutations Shift A $\beta$ Length by Destabilizing $\gamma$-Secretase-A $\beta$ n Interactions. Cell 2017, 170, 443-456.e14. [CrossRef] [PubMed]

33. Ch'ng, G.S.; An, S.S.; Bae, S.O.; Bagyinszky, E.; Kim, S. Identification of two novel mutations, PSEN1 E280K and PRNP G127S, in a Malaysian family. Neuropsychiatr. Dis. Treat. 2015, 11, 2315-2322.

34. Guerreiro, R.J.; Baquero, M.; Blesa, R.; Boada, M.; Brás, J.M.; Bullido, M.J.; Calado, A.; Crook, R.; Ferreira, C.; Frank, A.; et al. Genetic screening of Alzheimer's disease genes in Iberian and African samples yields novel mutations in presenilins and APP. Neurobiol. Aging 2010, 31, 725-731. [CrossRef] [PubMed] 